\title{
К СТОЛЕТИЮ
}

\section{ГУМАНИТАРНОГО ОБРАЗОВАНИЯ В САРАТОВСКОМ УНИВЕРСИТЕТЕ}

В 2017 г. высшему гуманитарному образованию в Саратовском университете исполняется 100 лет. В канун Октябрьской революции, решением Временного правительства России были открыты первые на огромном пространстве юго-востока Европейской России гуманитарные образовательные структуры высшей школы - историко-филологический и юридический факультеты.

Первым деканом историко-филологического факультета стал всемирно известный философ, профессор Семён Людвигович Франк (1877-1950). Гуманитарный мир гордится именами В. М. Жирмунского, Н. К. Пиксанова, М. Р. Фасмера, Г. А. Ильинского, А. П. Скафтымова, Г. А. Гуковского, Ю. Г. Оксмана, Е. И. Покусаева, Т. М. Акимовой и других выдающихся ученых-педагогов Саратовского университета.

Драматически сложно складывалась в XX в. судьба гуманитарного образования. Были и разные по своим последствиям перемены и структурные реорганизации, ценные обретения и невосполнимые утраты, обусловленные крутыми историческими маршрутами. В предлагаемой рубрике публикуются воспоминания и материалы, характеризующие историю саратовского университетского гуманитарного образования в лицах и документах.

УДК 821.161.1.09+792.2.(470-25)+929[Покусаев+Любимов]

\section{ЕВГРАФ ИВАНОВИЧ ПОКУСАЕВ И ЮРИЙ ПЕТРОВИЧ ЛЮБИМОВ: ДИАЛОГ В 5 ДОКУМЕНТАХ}

\section{В. В. Прозоров}

\author{
Саратовский национальный исследовательский государственный университет \\ имени Н. Г. Чернышевского \\ E-mail: prozorov@sgu.ru
}

Впервые публикуются и комментируются документы, проливающие свет на помощь, которую саратовский университетский ученый-литературовед Е. И. Покусаев оказал известному опальному режиссёру московского Театра на Таганке Ю. Л. Любимову в постановке спектакля по роману Н. Г. Чернышевского «Что делать?»

Ключевые слова: Н. Г. Чернышевский, «Рассказы о новых людях», Театр на Таганке, Юрий Петрович Любимов, Александр Александрович Лебедев, Евграф Иванович Покусаев.

Evgraf Ivanovich Pokusaev and Yuri Petrovich Lyubimov: a Dialogue in 5 Documents

\section{V. Prozorov}

For the first time the documents are published and commented on which shed light on the assistance that a Saratov university literary scholar E. I. Pokusaev rendered to a famous out-of-favor director of a Moscow Taganka Theatre Yu. L. Lyubimov in staging the performance on N. G. Chernyshevsky's novel What is to Be done?

Key words: N. G. Chernyshevsky, Stories of new people, Taganka Theatre, Yuri Petrovich Lyubimov, Alexandr Alexandrovich Lebedev, Evgraf Ivanovich Pokusaev.

DOI: 10.18500/1817-7115-2016-16-3-345-349

Представляется возможным воссоздать в пяти дошедших да нас документах одну из страниц истории художественной культуры советской поры, связанную с именами двух выдающихся людей - саратов-
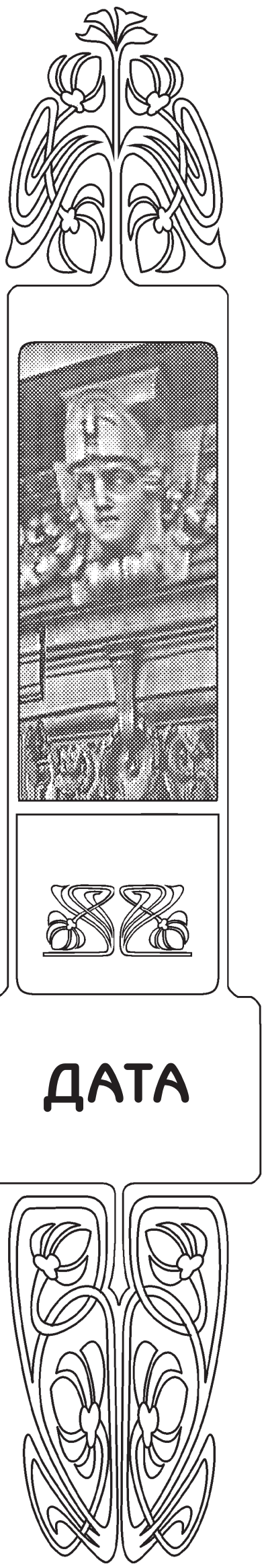
ского университетского литературоведа Евграфа Ивановича Покусаева (1909-1977) и московского театрального режиссёра Юрия Петровича Любимова (1917-2014).

История такова. 1970 год. Москва. Недавно последовавший разгром властями журнала «Новый мир» А. Т. Твардовского. Окончательно, после вторжения советских танков на Вацлавскую площадь в Праге, терпит фиаско «социализм с человеческим лицом». В начале 1970 г. по столице ползут слухи о том, что академик А. Д. Сахаров в соавторстве с В. Ф. Турчиным и Р. А. Медведевым в открытом письме руководителям страны выдвинул требование демократизации общества...

Заметный островок жёстко контролируемой свободы в стране развитого социализма - с 1964 г. успевший стать знаменитым на всю страну и на весь мир Театр на Таганке Ю. П. Любимова. Каждая новая его работа становилась событием и в мире искусства, и в жизни нашей страны, и в печальной истории отечественной театральной цензуры. Так, в 1968 г. был запрещен любимовский спектакль «Живой. Из жизни Фёдора Кузькина» по Борису Можаеву. В 1970 г. спектакль Театра на Таганке «Берегите ваши лица» по Андрею Вознесенскому был запрещен уже после премьеры. Травля из официальных подворотен не стихала.

Между тем неутомимый и дерзкий столичный режиссёр инсценирует и пробует поставить спектакль по мотивам романа Н. Г. Чернышевского «Что делать?» Властные инстанции по стойкой своей и трусливой привычке, конечно же, безусловного разрешения на постановку не дают: мало ли какие идеологические изъяны и политические подвохи упрятаны в новоиспечённой пьесе?! Но и запретить её «просто так» не решаются: год столетия В. И. Ленина, которого, как известно было каждому советскому школьнику, именно Чернышевский «всего глубоко перепахал»! Для перестраховки министерство культуры выставило театру требование - представить рецензии на инсценировку, принадлежащие авторитетным в науке о Чернышевском специалистам.

Очевидно коварство властного замысла. Известно, что в советскую эпоху на идеологически особо важных и ответственных участках, к которым относилось и наследие Н. Г. Чернышевского, по-хозяйски располагались свои неусыпные охранители. Их имена сегодня по большей части справедливо забыты, но в 1970-м они с высоты своих «выдержанных» идеологических позиций зорко и пристрастно следили за чистотой идейных помыслов «подозрительно незрелых» коллег по гуманитарному, общекультурному цеху.

Как в такой ситуации быть режиссёру и что делать? Ю. П. Любимов доверительно спрашивает совета у друга своего театра А. А. Лебедева. Александр Александрович Лебедев (1928-2002) - известный своими свободными от правоверного догматизма взглядами критик и историк русской литературы и общественного движения, автор широко почитаемых в российском гуманитарном мире работ о Грибоедове, Чаадаеве, Чернышевском, Плеханове, Луначарском, Антонио Грамши. Лебедев печатался в опальном «Новом мире», замечен был в постоянных симпатиях к Театру на Таганке, в прямом сотрудничестве с этим театром.

Сам он вряд ли мог в глазах власть предержащих быть «объективным» критиком любимовской инсценировки. Но Лебедев хорошо знал цену своим собратьям по литературоведческим занятиям. Выбор рецензента должен быть во всех смыслах безупречным и точным: театру нужна быстрая и надёжная помощь и поддержка.

И Лебедев делает такой выбор. Вернее, советует его сделать Любимову. Но сперва сам пишет человеку, в нравственных качествах которого не сомневается.

Адресат письма Лебедева - заведующий кафедрой русской литературы Саратовского государственного университета им. Н. Г. Чернышевского профессор Е. И. Покусаев. Саратов - родина Чернышевского, признанный центр изучения его наследия, а Покусаев - один из самых авторитетных исследователей творчества своего выдающегося земляка.

Талантливый ученик А. П. Скафтымова, Евграф Иванович Покусаев посвятил свою жизнь изучению творчества Салтыкова-Щедрина. После отъезда из Саратова Ю. Г. Оксмана и ухода на пенсию А. П. Скафтымова Покусаев - признанный лидер научной жизни филологического факультета Саратовского университета. Огромным педагогическим, редакторским, исследовательским трудом он приумножает авторитет саратовской школы литературоведения. Тонко исследует он особенности щедринского гротескного рисунка, взаимопроникновение комического и трагического, реального и фантастического начала, художественные и нравственные смыслы финальных решений в сатирических циклах и романах Салтыкова-Щедрина. Одна из вершин исследовательского искусства Евграфа Ивановича - анализ «Господ Головлевых», продемонстрировавший мастерство сатирика в изображении диалектики обманного, праздного слова, лишенного живого человеческого смысла и способного тиранить людей.

Работы Покусаева посвящены также истории русской литературной критики и журналистики XIX в. Его книга о Чернышевском за короткий срок выдержала пять изданий.

Покусаев (скажу на правах одного из многочисленных и благодарных его учеников) снискал себе славу талантливого учителя, зажигательного лектора, остроумного и азартного полемиста, неформального общественного деятеля. В его присутствии оживало любое полусонное официальное собрание. Одним комически неожиданным взглядом и иронически простодушной репликой он способен был взорвать любую казенную и пресную церемонию. 
К театру Евграф Иванович был особенно неравнодушен. Всячески поощрял творческие инициативы самодеятельного университетского студенческого коллектива под руководством Марка Зильбермана (впоследствии заслуженного деятеля искусств Чувашской АССР), ставившего в 1960-е гг. «Дракона» Евгения Шварца, «Клопа» Владимира Маяковского, «Белую болезнь» Карела Чапека. Пристально занимался драматургией Гоголя и не пропускал случая посмотреть новые постановки его пьес. Увлеченно делился с учениками и коллегами яркими впечатлениями от спектаклей Г. А. Товстоногова. Добрые отношения связывали Покусаева и с бессменным руководителем легендарного в российской провинции Саратовского театра юного зрителя, народным артистом СССР Ю. П. Киселёвым. Когда над нашим ТЮЗом сгущались очередные властные тучи, Покусаев, пользуясь своим авторитетом, воодушевлённо и смело защищал театр. Так было, в частности, при очень трудной сдаче одного из первых на отечественной сцене мюзиклов - спектакля по мотивам фонвизинского «Недоросля» (1970 г.). На саратовской сцене ставил его Леонид Эйдлин, а автором «зонгов» был запрещённый тогда Юлий Ким, вынужденный скрываться под псевдонимом Ю. Михайлов. Областные власти почуяли неладное. Устроили закрытый просмотр, за которым последовало закрытое же обсуждение увиденного. Премьера была под угрозой. Театр пригласил со своей стороны Покусаева. И Евграф Иванович сказал своё веское, доказательное, весёло-озорное слово. Сказал так, что после него дрогнули, отступили чёткие ряды стражей идеологического порядка...

А. А. Лебедев знал Покусаева не понаслышке, часто с ним доверительно общался. Лучше кандидатуры для помощи Ю. П. Любимову сыскать было трудно...

Перед нами письмо А. А. Лебедева Е. И. Покусаеву:

\section{Дорогой Евграф Иванович!}

Есть такой в Москве «Театр на Таганке». Bы, конечно, сльшали о нём. А может быть, $u$ видели что-нибудь в этом театре. Театр этот «модный». Есть в его работах и элемент некоей внешней эффектности и некоего «шума», что ли. Но есть у этого театра и доброе, честное, искреннее. Что - редкость. Нынче, вслед за «Новым миром», театр этот пережсивает трудную пору.

Не так давно театр решил поставить «Что делать?» Чернышевского. Но Министерство культуры чего-то забоялось тут. Возникли трудности, препятствующие началу работы. (Думаю, впрочем, что дело тут вовсе не в Чернышевском.) От театра потребовали рецензий специалистов на сиенарий! Юрий Петрович Любимов - гл. режиссёр театра, по моему совету, решил обратиться по этому поводу к Вам. Думаю, что (если, естественно, сиеническое решение романа не вызовет у Вас протеста, не оттолкнёт Вас) Bbl сделаете доброе дело и очень поможете театру в критический для него момент, поддержав эту его работу.

Сценарий родился в недрах театра. Я жесо своей стороны - согласился консультировать постановку. Обращение к Вам в данном случае представляется мне вполне оправданным и по существв, и внешне (Саратов-иентр «черныиевсковедения», Bы - руководитель этого ијентра). И титуль Ваши здесь необходимы.

Hу, вот и всё.

Положение у нас серьёзное. У меня лично ещё не так плохо. Только что прошла корректура 2-го издания моего Луначарского. С чем я связываю, в частности, и свои надежды писать Вам в будущем без угрызения совести. Здоровы ли Вы? Ежели найдёте время - напишите мне несколько слов.

Кланяюсь Вам. Ваш Ю. Лебедев 28.02.70.

Судя по всему, Е. И. Покусаев не замедлил с ответом и сразу же дал своё согласие на отзыв. Спустя две недели после письма Лебедева авиапочтой на бланке Московского театра драмы и комедии на Таганке пришла официальная бумага за подписью директора театра Николая Лукьяновича Дупака, датированная 10 марта 1970 года:

\section{Уважаемый Евграф Иванович!}

Обрашчаемся к Вам с большой просьбой. K 100-летию со дня рождения В. И. Ленина театр готовит спектакль «Рассказы о новых людях» по роману Н. Г. Чернышевского. Вам, вероятно, об этом писал А. А. Лебедев.

Нам бы очень хотелось знать Ваше мнение об этой пьесе. Ваши советы нам были бы очень полезны.

Просим прочитать пьесу и прислать нам Ваш отзыв.

С уважением Директор театра Н. Дупак.

Заваленный массой комментаторских, диссертационных, журнально-рецензионных, кафедральных, учебных и других забот, мужественно преодолевая близко уже подступавшую к нему тяжёлую болезнь, Евграф Иванович с ответом, тем не менее, не замедлил. Спустя ещё три недели на письме Н. Л. Дупака рукой Покусаева сделана короткая приписка: «отпр.[авлен] отзыв 31.03. - 1970».

Отзыв составлен так, что не оставляет официозным охранителям ни малейшего шанса на какие-либо претензии к инсценировке Ю. П. Любимова. Здесь и признание несомненных достоинств театральной версии романа Чернышевского, и заключение об абсолютной близости пафоса инсценировки и книги, и необходимые, марк- 
систскими авторитетами освещенные цитатные заслоны, и другие оборонительно-наступательные спасительные пассажи. Рецензия призвана отбить охоту у тех, кто горазд был методом изнурительных «придирок» и бдительных «прицепок» утопить инсценировку и обязанный ей своей жизнью спектакль.

По сути, этот отзыв - апология любимовской инсценировки, высшая похвала из всех возможных в ситуации обращения к роману «Что делать?». Покусаев тонко почувствовал главную особенность вольного режиссерского почерка Ю. П. Любимова, проявившуюся в том числе и в нехрестоматийном подходе к книге Чернышевского. В отзыве отчётливо говорится о так называемом принципе открытой игры. Он свойственен и Чернышевскому-романисту. Речь идет о неожиданном сближении известных повествовательных приёмов автора «Что делать?» с излюбленным любимовским способом сценического существования актера - художника и «человека из нашей жизни» в его эмоционально напряжённом и поразительно естественном общении со зрителем.

Отлично владея законами эзопова иносказания, Покусаев не отказывает себе и в удовольствии упредить «властные» реакции и мимоходом укорить самодовольно-невежественных и «ни бельмеса не смыслящих» в литературе и театре «оценщиков». Высказанные им и необходимые в таких случаях «замечания» носят отчётливо рекомендательный характер и выдержаны скорее в тоне комплиментарном: «...допускаю, что сценическое воплощение... всё поставит на свои места и, возможно, не без эффекта».

Приводим полностью этот текст, сохранившийся и в рукописи, и в авторизованной машинописной версии:

\section{$O$ Т 3 Ы В}

о пьесе Ю. П. Любимова «Рассказы о новых людях (об идиллиях, снах и реальностях по роману и другим произведениям Н. Г. Чернышевского)»

Нет нужды распространяться, сколь сложна творческая задача, за осуществление которой взялся автор новой драматической композиции по знаменитому роману Чернышевского. Сравнительно с предшествуюшими опытами в таком роде, насколько они мне известны, Ю. П. Любимов создал произведение, которое вплотную приблизилось к верной, образно-выразительной передаче пафоса "Что делать?»- пафоса общественно-сочиального, нравственно-психологического, идейно-философского. Покоряюшая сила романа Чернышевского заключалась в том, что он убеждал в истинности, красоте и величии нового, передового в жизни; отвечал на самый главный вопрос эпохи: что делать людям, ненавидящим старое, не желающим жить по-старому, стремящимся укоренить в жизни идеаль соичалистического будущего. Именно с этой стороны воспринимался роман властителями дум русской марксистской интеллигеничи (Г. В. Плеханов: "...кто не становился под его влиянием чище, лучше, бодрее, смелее?.. не задумывался над собственной жсизнью, не подвергал строгой проверке своих собственных стремлений и наклонностей? Все мы черпали из него и нравственную силу, и веру в лучшее будушее. "И доверенность великую К бескорыстному труду”». В. И. Ленин: «Он меня всего глубоко перепахал... Это вещьь, которая даёт заряд на всю жизнь»). Литературные достоинства предложенных для театральной постановки «Рассказов о новых людях» несомненны. Драматическое повествование Ю. П. Любимова, в пределах возможностей избранной формы, включило все существенные сюжетные линии романа: освобождение из домашнего плена, трактованное как история борьбы русской женщчины за свободу личности своей, за сочиальное равноправие; привлекательный мир новых человеческих отношений (Лопухов - Вера Павловна - Кирсанов); революиионно-рахметовская сфера. Удачно трансформировалась в пьесе необычайная композищия «Что делать?» (до романа Чернышевского в русской литературе не было, на мой взгляд, произведений столь сложно построенных), воссозданы главные композиционные пласты: «четыре пояса» (Луначарский) - «поилье люди», «новые люди», «выстие люди» и «сны»». Без нарочитости вошло в пьесу и всё то, что составляло специфику жанровой структуры романа: «воспроизведение жизни» в контрастных картинах «грязного», «злого» дворянскобуржуазного мира и светлого мира новых людей сопровождается открытым авторским «объяснением» того и другого. Как и в романе, в пьесе Ю. П. Любимова оно не скучно-назидательно. Это «объяснение» разнообразится ярким обличительным или призывным публицистическим словом, язвительным спором автора с «рабами» рутины («проницательный зритель»-собирательный тип реакционного обывателя, глупого, невежественного, самодовольного, назойливо берущегося рассуждать о вештах, в которых «ни бельмеса не смыслит...»), поражающим воображение широтой познаний и глубиной мысли, философским обобщением событий, прочессов вековой истории человечества и $т$. д. В речензируемой пьесе продемонстрировано искусство «монтажа», если последний понимать как ёмкий, подлинно творческий, иелеустремлённый приничи компоновки художественного материала. С тактом и образной чуткостью использованы, кажется, все потенциально-драматургические возможности романа -диалоги; острые повороты действия; конфликтные ситуачии; психологические, душевные напряже- 
ния; «сновидения» как романтические полёть мечты, как «заглядывания» в прошлое или в историческое завтра; образ повествователя, который получил в романе Чернышевского, как известно, некоторую композиционную (и сюжетную) автономию; и многое другое. Принцип «монтажа» распространён и последовательно проведен и в языковой ткани произведения. Кажется невероятным, но Ю. П. Любимов действительно обошёлся в пьесе стилистикой и речью романиста Чернышевского, языком персонажей «Что делать?», словом документального источника - административного, мемуарного, либо какого другого.

Что касается критических замечаний, то они сводятся к следуюшим немногим пунктам.

1. Несколько выпадает из концепџчи и стиля этой сиенической композиции её финал. В настоящем своём виде он словно бы из другой пьесы. Я имею в виду конкретное литературное решение заключительной части. В романе есть автобиографический материал. Включает его образ повествователя, «я» романа. Некоторые сцены (напр., пикника) и главы («Перемены декорачий») буквально прослоены «биографизмами». Так что у автора пьесы были основания завершить её тем или иным эпизодом (эпизодами) из реальной жизни Чернышевского. Но в таком случае финал должен быть исподволь подготовлен. Ведь логика повествования и в романе, и в пьесе ведёт и к финалу, условно говоря, "романическому», «литературному» (известно, что Чернылевский - узник Петропавловской крепости верил в револючионный взрыв в недалёком будущем), $и$ к финалу, так сказать, реально-историческому - судебной расправе над Чернышевским. Поколения читателей «Что делать?» имели в виду, держали в памяти своей и тот и другой аспекть окончания истории жизни новых людей. Вовсе не бесспорен вопрос, какой из этих аспектов и для революиионного поколения Ленина и в настоящее время наиболее актуален.

2. В пьесе (в её настоящем виде) комментируют происходящее многие «голоса», многие эпизодические лица, порой индивидуально неразличимые, на мгновенье появляюшиеся. Невольно возникает желание что-то здесь прокорректировать. Впрочем, допускаю, что сценическое воплощение этого литературного ряда всё поставит на свои места и, возможно, не без эффекта.
В ичелом же драматургия «Рассказов о новых людях» Ю. П. Любимова добротна литературно, идейно, сиенически.

Доктор филологических наук, профессор Саратовского университета

Е. И. Покусаев

31 мapma 1970

Саратов

Спектакль Ю. П. Любимова состоялся. Премьеру сыграли 18 сентября 1970 г. Сегодня в Интернете доступна его аудиоверсия. В «Рассказах о новых людях» заняты Леонид Филатов (Автор), Зинаида Славина (Вера Павловна Розальская), Инна Ульянова (Мария Алексеевна Розальская), Валерий Золотухин (Лопухов), Дальвин Щербаков (Кирсанов), Александр Трофимов (Рахметов), Нина Шацкая (Невеста всех невест), Семён Фарада (Жан, Буфетчик, Важный господин, Извозчик), Иван Дыховичный (Серж), Марина Полицеймако (Матрёна, горничная Розальских) и многие другие. На сцене воссоздан был амфитеатр длинных студенческих скамей с высокими спинками. Театр словно бы представлял собой одну большую лекционную аудиторию. Сценическое оформление (художник Давид Боровский) органично объединяло сцену и зрительный зал, выявляя много неожиданных постановочных возможностей для аллюзионного звучания романа Чернышевского...

И наконец, документ, завершающий наш рассказ. Речь о письме Ю. П. Любимова Е. И. Покусаеву (без даты, на фирменном бланке Театра на Таганке):

Дорогой Евграф Иванович!

Я бесконечно тронут Вашим тёпльмм отзывом.

Весь Ваш интересный и тонкий разбор очень помогал нам в работе. бимов

С глубоким, искренним уважением - Ю. Лю-

P. S. Прошу извинить меня, я был очень задёрган трудными обстоятельствами по работе.

Документально подтверждаемый диалог Е. И. Покусаева и Ю. П. Любимова - одно из свидетельств деятельного солидарного сопротивления, которое люди науки и искусства, по-настоящему умные, честные и совестливые, исподволь оказывали мрачным и душным предлагаемым обстоятельствам нашей общественнокультурной жизни. 